\title{
Remedying Misdemeanors At South African Higher Education And Training Institutions
}

\author{
Mutendwahothe Walter Lumadi, North West University, South Africa
}

\begin{abstract}
ABSTARCT
In 2004 South Africa embarked on a mission of reforming its higher education system, merging and incorporating small universities into larger institutions, and renaming all higher education institutions university. The democratic country's universities and technikons, which were incorporated with others and thus no longer exist, will be mentioned in this study. There are also a large number of institutions in South Africa, some are local campuses of foreign universities, some conduct classes for students who write their examinations at the distance education University of South Africa and some offer unaccredited or non accredited diplomas. Public universities in South Africa are divided into three types; traditional universities, which offer theoretically oriented university degrees; universities of technology, which offer practically-oriented diplomas and degrees in technical fields; and comprehensive universities, which offer a combination of both types of qualifications. Disciplinary problems at universities interfere with the educational process and place a burden on Management and academics. Misdemeanours have long been linked to negative outcomes for students, such as course failure and dropping out of universities. University senior management team is interested in keeping the institution safe and maintaining positive environment conducive to learning. To accomplish this mission, universities employ a range of policies and approaches to managing student behaviour, including positive behaviour support, exclusion, suspension and expulsions. Research was conducted in three types of South African universities. Management of each type of university was interviewed. From each type of university, three institutions were randomly selected. This left the researcher with a total of 9 universities out of 23. Responses from management of various institutions were related.
\end{abstract}

Keywords: Remedy: Solution (to problems), Misdemeanours: Disciplinary challenge or problems, HET: Higher Education and Training (Institutions of higher learning), HETI: Higher Education and Training (Institutions of higher learning i.e. universities)

\begin{tabular}{|c|c|c|c|c|c|}
\hline \multicolumn{7}{|c|}{ Table 1: South African Universities } \\
\hline \multicolumn{5}{|c|}{ Traditional universities } \\
\hline Cape Town & Fort Hare & Free State & KwaZulu-Natal & Limpopo & North west \\
\hline Pretoria & Rhodes & Stellenbosch & Western Cape & Witwatersrand \\
\hline \multicolumn{7}{|c|}{ Total number 11 } \\
\hline
\end{tabular}

Cape Town (Cape Town) Fort Hare (Alice \& East London) Free State (Bloemfontein) KwaZulu Natal (Durban Pitermaritzburg, Pine Town \& Westville) Limpopo (Polokwane \& Garankuwa) North West (Mafikeng, Mankwe, Potchefstroom \& Vanderbijlpark) Pretoria (Pretoria) Rhodes (Grahamstown) Stellenbosch (Stellenbosch) Western Cape (Cape Town) Witwatersrand (Johannesburg)

\begin{tabular}{|c|c|}
\hline Table 2: Comprehensive universities \\
\hline Johannesburg (Johannesburg) & Nelson Mandela (Port Elizabeth) \\
\hline UNISA (Pretoria distance education) & Venda (Thohoyandou) \\
\hline Walter Sisulu (Buffalo City, Butterworth, Mthatha \& Queenstown) \\
\hline Zululand (Empangeni) \\
\hline Total number: 06 \\
\hline
\end{tabular}




\begin{tabular}{|l|l|c|}
\hline \multicolumn{3}{|c|}{ Table 3: Universities of technology } \\
\hline Cape Peninsula (Bellville \& Cape Town) & Central (Bloemfontein \& Welkom) \\
\hline \multicolumn{3}{|c|}{ Mangosuthu (Durban) } \\
\hline \multicolumn{3}{|c|}{ Taal (Vanderbjlpark) } \\
\hline \multicolumn{3}{|c|}{ Total number: 06 } \\
\hline \multicolumn{3}{|c|}{ Total number of all South African universities: 23 } \\
\hline
\end{tabular}

\section{FINDINGS AND RECOMMENDATIONS IN THE STUDY}

Various findings were identified in the study and recommendations for each finding were also given.

\section{Scholastic Dishonesty}

Stoll and Fink (1997: 196) show that scholastic dishonesty entails plagiarism, collusion or cheating on any examination or classroom assignment. Cheating includes, falsifying data by presenting data of laboratory reports, projects and others as one's own when this data is based on experimental work conducted by another party.

- Students copy from an examination paper of another candidate; they engage in any means of communication with another student during a test, examination or seek aid from another student during a test.

- $\quad$ They are found in possession or use during an examination or test of books that are not allowed by the examiner or Chief invigilator such as lecture notes, or handkerchief, tissue papers with notes or writing notes on parts of the body such as palms, hands or thighs

- $\quad$ Furnishing credentials that have been earned by another student, or falsifying records, transcripts, or other academic papers in order to falsely present one's academic position

- Impersonating a candidate at an examination or availing oneself of such an impersonation.

- It is presumed that material submitted by a student for an assignment is original to that assignment and, therefore, submitting the same work for more than one course without the consent of the examiners or supervisors of each course in which the work is submitted is considered dishonest and it is tantamount to duplication (Schwartz \& Cavener, 1996: 330).

Most acts of academic dishonesty involve cheating in examination in one way or another, improperly obtaining examination questions, plagiarism, forgery, and falsification of records or impersonation of a candidate taking an examination. Students who are caught cheating are removed from the examination room. Their scripts together with the scribbling, which is evidence is forwarded to the attention of the Chief Examinations Officer. As a result, they forfeit credits for that particular examination. Undergraduate students who are doing their final year are barred from registering in the following year. Should they be found committing the same offence during their period of study with the same institution, they are expelled.

Postgraduate students who are caught cheating in examinations are dismissed and are not allowed to reregister with the same institution. Other institutions were the student might intend to register with, are provided with the bad record of the student. This limits the student's chances of getting admission. Those who plagiarize with masters' dissertations and doctoral theses face a similar charge.

Higher Education and Training Institutions (HETI) recognize that any form of academic dishonesty challenges the principles of accountability, responsibility integrity and respect. Consequently, institutions treat academic dishonesty as a serious violation of academic trust. It penalizes all students found to have engaged in such behaviour. It does not compromise the standing of the institution as a degree conferring authority as this might have an impact on quality assurance.

Individual records of academic dishonesty should be kept completely separate from the individual student transcript and any other records. The only person who has access to the records is the campus registrar. The campus registrar can release them to the chairperson of the students' Disciplinary Hearing when they are required. Once the 
student leaves the university, bad records are of little use, but four years after graduation, the academic dishonesty records of the student should be destroyed.

\section{Vandalism}

Soni (1997:23) views vandalism as the intentional abuse, damage or destruction of any portion of residential facilities, furnishing or property. Examples thereof include, amongst others punching in a ceiling tile, removing an exit sign and failing to clean up vomit after an incident in the hallway. Vandalism is strictly viewed as a campus crime control issue. This is a serious misdemeanour, as it affects the reputation and standing of the institution and its degree. It impacts negatively on quality assurance. It is worth noting that student vandalism at university is a complex problem with no easy single solution. Data collected shows that vandalism takes many forms, from trashing dormitories to stealing property and writing graffiti. Student vandalism is also associated with binge drinking, peer pressure, the need to obtain money to buy drugs, hostility towards the institution, or a combination of these and other factors.

Dormitories and other campus buildings near bars or other places where alcohol is served may bear the brunt of vandalism associated with drinking. Deans of Faculties interviewed for this study identified intoxicated students leaving sporting events and fraternity parties as the primary cause of vandalism. This research also found that vandalism is also associated with some sort of partying and was likely to be committed within a dormitory. Drunken students compete by hoisting a couch or some piece of furniture out of dormitories windows. Other physical damage to buildings writing and drawing funny pictures on the walls of bathrooms and the destruction of furniture especially chairs and sporting equipment are also common results of excessive student drinking (Lumadi, 1999)

It is recommended that Faculties approach vandalism as a health issue, which requires addressing the offender's abuse of alcohol or drugs. These strategies include prevention programming based on the notion of family ties and referring students who commit no criminal acts of violence for recommended evaluation and counselling. In view of the complexity of the vandalism problem, Faculties should be most effective in putting a dent in the problem by adopting both strategies using punitive measures, and providing appropriate substance abuse preventing and treatment services. The following control strategies should also be resorted to;

- $\quad$ Using trained students to patrol large campus events and dormitories

- Implement target hardening strategies such as controlling access to frequency vandalized campus locations like parking lots and restrooms

- $\quad$ Establish substance free residence halls

Disciplinary measures should be publicized to serve as a deterrent. Students should check on parties in progress to make sure there is no vandalism, sexual misconduct, fighting or other misbehaviour. Security should train the students to confront violent situations, to write up violations of university policy they may encounter during their patrols, ad to call the security if there is any violence. Improved relations with the local community should become an important benefit of targeting any problem related to vandalism.

The SRC should begin working with local security and party hosts to develop approaches of addressing excessive weekend partying before it becomes a problem. Some of the approaches that should be put in place include improved security at campus events and expanded substance free prevention programming. Faculties should help prevent the type of disturbance that occurs in hostel by carefully reviewing their own alcohol and other drug policies, and by ensuring that these policies do not advertently encourage drug use and excessive drinking. Faculty administrators should also urge local bars to stop serving alcohol to underage drinkers and intoxicated local drinkers.

In campus dormitories, students should patrol in pairs, serving as the eyes and ears for campus police. When they observe vandalism, they should call security to take appropriate action. Security departments' staff should carry radios, which are still in operation and should be dispatched through the security dispatcher. 


\section{Sexual Harassment}

Walzer (1996: 148) views sexual harassment as entailing uninvited physical conduct directed at a person because of his or her race, language, colour religion, age, disability, sexual orientation, or group affiliation, policies, HIV and AIDS status. Unwelcome sexual nature advances, requests for sexual favour and other verbal conduct of a sexual nature constitutes sexual harassment (Schaller, 1998: 66). Promoting a female student after sexual intercourse or failing her when she refuses to succumb to a situation of sexual advance is illegal. This offence also refers to sexual abuse including rape or physical abuse or detention, of any person on university controlled property or at any campus sponsored function.

Respondents also identified the following common examples of sexual harassment at HETI.

- $\quad$ Repeatedly using degrading words or sounds to describe a person such as "fatty boom boom, shorty, tally, fit for it."

- $\quad$ Sexual advances, sexual propositions, or sexual demands which are not agreeable to both parties

- $\quad$ Unwanted and unnecessary touching, patting, hugging, or other physical contact

- $\quad$ Threats of insinuations which lead the victim reasonably to believe that granting or denying sexual favours will affect her or his reputation, education, advancement or standing with the university

- Unwelcome and persistent sexually explicit statements or stories which are not legitimately related to course content, research, or other university programs or activities

- $\quad$ Recurring questions or comments about an individual's sexual prowess, sexual deficiencies, or sexual behaviour

For the university to investigate and respond to alleged sexual harassment, the complaint should be made as promptly as possible after the alleged sexual harassment occurs. A student who believes that he or she has been sexually harassed may also elect to file a complaint with the SRC office or to file a grievance against the alleged harasser under applicable university procedure. The submission of such a complaint does not affect the university's ability to take disciplinary or other administrative action even though the complaint or grievance is still pending.

Each complain of sexual harassment must be evaluated with reference to the pertinent circumstances. On occasion, a complaint will be resolved informally. Other complaints will result in investigations, including interviews and review of documentary material. Both the complaint and the alleged harasser should be notified of the outcome of the investigation. If an investigation results in a determination that sexual harassment has occurred, the university should take remedial, including where appropriate, disciplinary action.

\section{Rape}

Krizmanic and Kolesaric (1996:53) view rape as forcing someone to submit to sexual intercourse. It can also be defined as unlawful sexual intercourse with a woman without her consent. The phenomenon of rape on university campus has received much needed attention during the interviews. Two steps are recommended under rape namely; reporting on the one hand and investigation on the other hand. Any student who is a victim of rape should as soon as possible;

- $\quad$ Report the incident to the campus security that should assist her to report the matter to the nearest police station.

- $\quad$ Seek medical attention and do not interfere with the preservation of evidence such as bathing, combing hair or changing clothing

- $\quad$ Meet with the dean of the Faculty or dean of students. Every effort should be made to assure the privacy of the victim and the accused both during and after any investigative and adjudicative process. Upon request by either party, the university will help to prevent any unwanted contact between the complainant and the accused. 
Rape by any student member of the community occurring on university property or at a university sponsored event is a violation of accepted student behaviour, which can lead to disciplinary hearing. All students have the right to study and live in an environment that is free from sexual or physical intimidation. All women and men have the right to be treated with respect at all times. HETI acknowledge the moral, legal, physical and psychological seriousness of all sexual assaults. This includes the commonly designated acquaintance rape or forced sexual behaviour, including intercourse between persons who already know one another, however casually. The optimal approach and most appropriate solution to this issue is for all persons to develop and live by a value system which respects other person's bodily integrity and sacredness of human sexuality. HETI is committed to pursue that goal.

\section{Theft}

Arjun (1998:24) refers to theft as an unauthorized use, taking or withholding of anything of value belonging to another individual. Theft is felony; it is the taking of someone else's property with the intention of permanently depriving that person from it. Respondents indicated that articles, which are always stolen, are;

- Jewellery including necklace, bracelets, ear and finger rings and also watches in hostels

- $\quad$ Clothing especially jeans and shoes, which are sold to outsiders

- $\quad$ Equipment such as TV's, computers, fridges, microwaves, kettles, flasks, irons

- $\quad$ Radios, music systems and CDs. These are sold at cheap prices to taxi drivers

- $\quad$ Heaters in winters and fans in summer

- $\quad$ Wallets, loose cash, ATM cards and cheque books

- $\quad$ Valuables such as cell phones

Students should take precaution against the possibility of theft or personal items. To aid the student effort, the following is required;

- Students should not leave windows open, nor tamper with the locking mechanism, as it is tantamount to victim precipitation

- $\quad$ Always keep residence room locked when unoccupied or sleeping. For security reasons, exterior doors should always be secured all times

- $\quad$ A record of all serial numbers of valuables items should be kept in a safe place. In addition a student's initials should be engraved on all items

- $\quad$ Large amounts of cash should never be kept in a student's room. Money should always be kept at the bank

- $\quad$ All clothing should be marked in such a way that it can be easily identified

The university cannot be held responsible for stolen money or articles, however, it will assist the student recovering stolen items and in the apprehension of the suspect when possible. Evening and weekend patrols should monitor theft, watching for rowdy, intoxicated students. The patrols should then approach the students and advise them that theft will be punished firmly and swiftly. Being identified as a potential thief and receiving a warning could deter even an intoxicated student from doing damage. When theft occurs, it might be easier to identify the offender. The institution should improve lighting process. Lights should be on in the evening. Those with problem should be fixed as a matter of urgency to combat theft.

\section{Alcohols And Drug Abuse}

Alcoholism and drug abuse has received a great deal of attention from respondents. Although some alcoholic students perform their task satisfactorily, and meet academic standards, others struggle. This is exacerbated by alcohol and drugs abuse. Alcohol and other drug abuse is a major factor in chronic diseases and the spread of infectious diseases. Students should be aware of the health risks associated with alcohol and drug abuse. Each individual will experience the effects of alcohol and drugs in a slightly different way given his or her tolerance, body size, family history, gender and other physical and psychological factors. Abuse of alcohol and drug can lead to chemical dependency. 
In small doses barbiturates produce calmness, and lowered anxiety. Larger dose cause slurred speech, staggering gait and altered perception (Lumadi, 1999:11). Very large doses taken in combination with other central nervous system depressants, e.g. alcohol have serious effects of causing respiratory depression, coma and sometimes death Marijuana usually leads to a substantial increase in heart rate. It impairs short-term memory and comprehension. Narcotics including heroin, codeine, opium and percodan are usually injected. The use of contaminated needless may result in HIV and AIDS and hepatitis. Health risks Amphetamine use causes increased heart and respiratory rates elevated blood pressure and dilated pupils. Hallucinogens interrupt the part of the brain that controls the intellect and impulsive behaviours. Cocaine may cause insomnia loss of appetite and paranoia and death. Some of the control measures to be taken by universities are identified beneath.

- $\quad$ Rehabilitation programmes for students suffering from alcoholism should be implemented. Organizations that can assist tin this regard are the South African National Council on Alcoholism and Drug Dependency (SANCADD), Alcoholics Anonymous AA, the Department of Health and family doctors.

- $\quad$ Alcoholic students should be confronted in a firm and supportive manner. The session should be nonthreatening

- $\quad$ Both vertical and horizontal communication should be promoted

- $\quad$ No student under the age of 21 should possess or consume alcohol

- Outdoor public drinking of alcoholic beverages on premises owned, leased or controlled by the university should be strictly forbidden. This includes walkways, buildings, residential steps or porches unenclosed patios, lawns and the like regardless of the age of the drinker

- Off campus possession, use distribution or sale of narcotics or drugs by students is inconsistent with university's policies, and should be forbidden

- $\quad$ Any type of drug paraphernalia including but not limited to bongs, pipes, any items modified adapted so that they can be used to consume drugs are not permitted on university premises

- The university should not confiscate drugs or drug paraphernalia when found on university property, instead it should be reported to the nearest police station

\section{OTHER PENALTIES FOR COMBATTING MISDEMEANORS}

\section{Exclusion}

All students who are excluded from university facilities are prohibited from attending a class, or entering a building. Such students are barred from participating in an extra-curricular activity sponsored by the university, representing the university in an official capacity, or using other services provided by the university.

\section{Expulsion}

Expulsion from the university is with notice to all students depending on the type of offence. Readmission is not permitted to students who have been expelled. Expulsion of students is with or without notice to all students depending on the type of offence. If an offence warrants expulsion, it cannot be negotiated.

\section{Suspension}

Suspension from the university is for a period of time, subject to conditions, which are justifiable on educational grounds and acceptable within the institutional culture of the university. Suspension for a specific period of time prohibits students' participation from any activity at HETI premises. The student on who it is imposed cannot receive credit for scholastic work done during the period of the suspension. Students are expelled due to scholastic dishonesty. Suspended students are barred from participating in extracurricular activities. They are not eligible to participate in official events of the campus. 


\section{CONCLUSION}

From the foregoing discussion, it became evident that there are numerous challenges regarding transgression of disciplinary code and prevention of misdemeanours at HETI. It is worth pointing out that this study did not include all the challenges experienced by management at institutions of higher learning because research of this nature is limited due to time and the scope of the discipline. When a student violates the code of conduct, the university's response will be corrective rather than punitive in order to ensure that the student may learn to exercise his or her freedom responsibly. In those egregious cases where the demonstrated misbehaviour is extraordinary to the learning process and cannot be tolerated, a student may be expelled from the university. Achieving the required knowledge skills and values of mind to promote a prosperous and democratic South Africa will warrant dedication from students.

\section{REFERENCES}

1. Arjun, P. 1998. The pocket oxford dictionary of English $.11^{\text {th }}$ edition. Oxford: Clarendon Press.

2. Krizmanic, M. and Kolesaric, V. 1996. The meaning and importance of culturally determined implicit values for the internationalization of education. Higher education in Europe. Xvi920; 46-60.

3. Lumadi, M.W. 1999. Restoring the culture of learning. A case of the Limpopo Province. Conference proceedings. USA: George Washington University.

4. $\quad$ Miller,W.L.and Crabtree, B.F. 1999. Doing qualitative research. Newbury Park: Sage Publications.

5. Schaller, M. 1998. Sample size, aggregation, and statistical reasoning in social inference. Journal of experimental social psychology, 28 (1) 65-85.

6. Schwartz, G. and Cavener, L.A. 1996. Outcomes-Based Education and curriculum change: advocacy, practice and critique. Journal of curriculum and supervision. 9(4): 326-338.

7. Soni,P.D. 997. The significance of culture in education. Vital11 (1) 13-25.

8. Stoll,L and Fink,D. 1997. Effecting school change: The Halton approach. School effectiveness and school improvement. 3 (1): 19-41.

9. Walzer, M. 1996. Education, democratic citizenship and multiculturalism. Towards Philosophy of education society of Great Britain. 29 (2) 186.

10. Welman, J.C. 1999. Research methodology for business and administrative Sciences. Cape Town: Oxford University Press. 


\section{NOTES}

